\title{
Covid collective

\section{The socioeconomic impacts of the Covid-19 pandemic on forcibly displaced persons}

\author{
Brigitte Rohwerder \\ Institute of Development Studies \\ 19 July 2021
}

\section{Question}

- What socioeconomic impact has Covid-19 had on forcibly displaced people? What do examples, ideally from selected Covid Collective countries, tell us about

- challenges, opportunities and innovation among forcibly displaced people affected by Covid-19, and

- intersectional inequalities among forcibly displaced people, and opportunities to respond to or address these?

\section{Contents}

1. Summary

2. Interlinking crises facing forcibly displaced persons

3. Economic impacts

4. Social impacts

5. References

The Covid Collective helpdesk service provides brief summaries of current research, evidence, and lessons learned. Helpdesk reports are not rigorous or systematic reviews; they are intended to provide an introduction to the most important evidence related to a research question. They draw on a rapid desk-based review of published literature and consultation with subject specialists.

This Helpdesk report was commissioned through the Covid Collective based at the Institute of Development Studies (IDS) and is funded by the UK Foreign Commonwealth and Development Office (FCDO) The Collective brings together the expertise of, UK and Southern based research partner organisations and offers a rapid social science research response to inform decision-making on some of the most pressing Covid-19 related development challenges. The views and opinions expressed do not necessarily reflect those of FCDO, the UK Government, or any other contributing organisation. For further information, please contact covidcollective@ids.ac.uk 


\section{Summary}

Covid-19 and the response and mitigation efforts taken to contain the virus have triggered a global crisis impacting on all aspects of life. The impact of the Covid-19 pandemic for forcibly displaced persons (refugees, internally displaced persons and asylum seekers) extends beyond its health impacts and includes serious socioeconomic and protection impacts. This rapid review focuses on the available evidence of the socioeconomic impacts of the crisis on forcibly displaced persons, with a focus where possible and relevant on examples from countries of interest to the Covid Collective programme: Afghanistan, Bangladesh, Ghana, Iraq, Kenya, Malawi, Pakistan, Rwanda, South Sudan, Syria, Uganda, Yemen, Zambia and Zimbabwe.

The available evidence is a mix of quantitative and qualitive research published mainly in grey literature reports from organisations working in this area, as well as a few journal articles. Some of the literature draws on lessons from before the pandemic, but where possible the focus was on literature focusing on empirical research gathered during the pandemic. There is more evidence available from the first year of the pandemic, although some more recent research has also been included. While most papers focus on the experiences of refugees, a number look at the experiences of internally displaced persons. There was little specific focus on the intersectional experiences of forcibly displaced persons, although a few reports focused on the experiences of women and girls or children.

\section{Key findings}

- Economic impacts: Forcibly displaced persons were at an economic disadvantage before the pandemic and often work in the informal sector, which has been severely impacted by the measures taken to combat the spread of the virus.

- As a result, many forcibly displaced persons have lost their jobs or income, pushing them further into poverty. Refugees were more likely to lose their jobs or income than members of the host community. Women were more likely to lose their jobs or income than men.

- Forcibly displaced persons were unable to meet basic needs and afford to cover expenses such as food, health care, rent and education. This resulted in increased tensions and stress within households.

- Food insecurity is a major concern for forcibly displaced persons, owing to a combination of factors, such as lost income and livelihoods, increased food and transport costs and food shortages. This was reported to be especially concerning for displaced women and children as they are often responsible for getting food, so the stress falls on them. Furthermore, they may be a lower priority when scarce food is distributed. Parents were aware of the negative impact of poor diet or lack of access to food on children.

- Forcibly displaced persons coped with their loss of income by reducing food consumption or eating less nutritious food (as nutritious food is often more 
expensive), borrowing money, reducing spending on other household essentials, increased utilisation of savings and/or selling of assets, and being compelled to accept work (including sex work) under exploitative conditions. Especially concerning were the rises in child labour and child marriage as means for families to deal with the pandemic's economic pressures.

- Many government social protection systems and responses to the pandemic did not cover forcibly displaced persons, and humanitarian and development actors struggled to provide assistance as a result of decreased funding, travel bans, local lockdowns and staff illness during the pandemic. As a result, the provision of social protection and humanitarian aid for forcibly displaced persons during the pandemic was limited and inconsistent. They often received less than they had previously, and not enough to meet their basic needs. Urban refugees were less likely to get assistance than those in camps or settlements as assistance is often focused on camps and settlements.

- Social impacts: Access to education was a major issue for forcibly displaced children because of widespread school closures and difficulties with home schooling. In addition, their economic pressures meant families were less likely to send their children back to school when schools were open, with girls particularly at risk of not attending any more.

- Lockdown measures and confinement, as well as heightened socioeconomic pressures and school closures, have increased displaced women and girls' risks of gender-based violence. In Afghanistan, for example, women felt that this was due to increased male unemployment. Forcibly displaced women and girls, especially if they are undocumented, are reluctant to access genderbased violence services because they fear retaliation, stigma, detention and possible deportation if such services are not firewalled.

- Forcibly displaced women and girls have also struggled to access sexual and reproductive health services during the pandemic.

- Forcibly displaced persons have experienced increased stigma, discrimination and xenophobia during the pandemic, especially for those with insecure status.

- Fear of Covid-19 and its increasing socioeconomic impacts has resulted in increasing tensions between displaced populations and host communities in some countries, sometimes tapping into existing tensions.

- The pandemic has also reduced access to registration and civil documentation, which has knock-on effects on access to essential services and legal rights to stay.

\section{Interlinking crises facing forcibly displaced persons}

Covid-19 and the response to it have triggered a global crisis that has exacerbated and deepened pre-existing inequalities, with its impacts being felt most by groups that were already marginalised and excluded before the crisis began (Rohwerder 2020: 9). The pandemic has made an already difficult situation worse for many forcibly 
displaced persons, magnifying the inequalities they faced and compounding their risks (Anaam 2021: 497; Amnesty International 2021; Osborn 2021: 2). Forcibly displaced persons include refugees, internally displaced persons and asylum seekers, who have fled their homes to escape violence, conflict and persecution. The United Nations (UN) (2020: 2) and others note that the Covid-19 pandemic has resulted in three interlinking crises for forcibly displaced persons, who were already in vulnerable positions before the outbreak: a health crisis, a protection crisis and a socioeconomic crisis.

The health crisis relates to their increased susceptibility to the virus, due to their often poor and overcrowded living and working conditions, which make it harder for them to take preventative measures, and their difficulties accessing health care (including Covid-19 vaccinations), especially if they are undocumented and at risk of arrest or deportation (UN 2020: 2; Vallette et al. 2021: v; Amnesty International, 2021: 14; WHO 2020: viii; Douedari et al. 2020: 6).

The protection crisis relates to movement restrictions and the closure of borders, both of which have contributed to the further erosion of the right to seek asylum and the principle of non-refoulement (according to which no one should be returned to a country where they would face torture, cruel, inhuman or degrading treatment or punishment or other irreparable harm) (UN 2020: 2; Rohwerder 2021; Hazard 2020: 20). At the initial height of the pandemic an estimated 168 countries limited or cut off access to asylum as they fully or partially closed their borders (Rohwerder 2021: 6). These countries generally made no exceptions for asylum seekers in relation to entry across their borders, despite this being against international law and not justified on the grounds on any health risk (Rohwerder 2021: 5). There have been violent pushbacks of asylum seekers across the world, both at sea and on land (Rohwerder 2021: 6). Observers note that 'Covid-19 is being used by some governments as an excuse to block people from the right to seek asylum and implement their nationalist agendas of border closures and anti-immigration policies' (Rohwerder 2021: 4).

The socioeconomic crisis relates to the disruption the pandemic has caused to the already precarious livelihoods of forcibly displaced persons, impacting on their food security and their ability to send their children to school, as well as increasing their risk of exposure to gender-based violence, abuse and exploitation (UN 2020: 2; Amnesty International 2021: 5; Gorevan 2020: 3). The Covid-19 pandemic is also causing humanitarian funding diversions and cuts, which affect the access to vital services of many forcibly displaced persons across different settings (Vallette et al. 2021: 21; Amnesty International 2021: 22; Anaam 2021: 498).

This report focuses on the socioeconomic crisis forcibly displaced persons are facing during the ongoing pandemic. Where possible and relevant, examples are drawn from countries focused on by the Covid Collective. 


\section{Economic impacts}

\section{Loss of livelihoods and increased poverty}

In many countries forcibly displaced persons were already at an economic disadvantage and are often barred from the formal labour market, which means they tend to work in the insecure informal sector if they are able to find work at all (Jacobsen et al. 2020: 77; Hazard 2020: 18; Vishvanath et al. 2020: 12). They face aggravated risks of poverty because of 'the pre-existing fragility of their living conditions and livelihoods; a low level of assets; limited coping strategy options; restricted access to social safety nets; and reliance on humanitarian assistance' (Vishvanath et al. 2020: 11). Lockdowns, travel restrictions, physical distancing and other measures taken to combat the spread of the virus have had a severe impact on economic activity, especially for the informal sector (UN 2020: 11; Amnesty International 2021: 17; Duclos and Palmer 2020: 10; Rohwerder 2020: 10-15). In addition, the cost of food, transport and other commodities has often increased at the same time as people have lost their livelihoods (Douedari et al. 2020: 6; Guglielmi et al. 2020: 5). Furthermore, people working in the informal sector are not generally covered by social protection measures (UN 2020: 14; Rohwerder 2020: 50). Women refugees are also often overrepresented in this sector, which means that the Covid-19 pandemic is likely to increase their economic vulnerability (Dempster et al. 2020: 15, 17; Bukuluki et al. 2020: 3). Forcibly displaced persons often have very few, if any, reserves, no contingency livelihoods, and weaker social support networks to protect them against economic shocks, so they are 'among the hardest hit by reduced incomes [and] increasing unemployment, as well as increasing expenses and price hikes for basic commodities' (UN 2020: 11; Bukuluki et al. 2020: 3). The economic impacts of the pandemic are causing considerable distress to people affected (Gorevan 2020: 18). Worries about lost livelihoods and the consequences of this may be a greater concern for displaced populations than Covid-19 itself (NRC 2020b: 2).

\section{Evidence from around the world}

A survey carried out by World Vision in May 2021 of 339 households consisting of refugees and internally displaced persons (representing 1,914 people) in Brazil, Colombia, the Democratic Republic of Congo, Jordan, Peru, Turkey, Uganda and Venezuela found that 72 per cent of respondents reported a drop in income and 40 per cent said they had lost a job (Vallette et al. 2021: vi). The top three reported reasons for income reduction were job loss, decline in revenue (for small business owners) and salary decreases (Valette et al. 2021: 11). Women were more likely to report income losses than men (64 per cent compared to 36 per cent of men), primarily as a result of disruption to the industries in which they worked (Vallette et al. 2021: 11).

A survey by the Norwegian Refugee Council (NRC) in late August 2020 of 1,400 people affected by conflict and displacement in eight countries found that 77 per cent had lost a job or income from work, temporarily or permanently, since the beginning of 
the pandemic (Gorevan 2020: 3). In Iraq for example, women were more likely to lose their jobs permanently than men (52 per cent compared to 34 per cent) (Gorevan 2020: 22). In addition, 62 per cent of respondents who had previously received remittances from family members abroad said they were receiving less than before the pandemic (Gorevan 2020: 3, 11).

The United Nations High Commissioner for Refugees (UNHCR) found that 89 per cent of internally displaced persons surveyed in Iraq reported loss of employment since the start of the Covid-19 pandemic (Duclos and Palmer 2020: 10). UNHCR (2021b) also notes that 1.1 million Syrian refugees and internally displaced Iraqis were pushed into poverty as a result of Covid-19. Research with 129 Syrian refugee families living in Lebanon found that 79 per cent of the breadwinners had lost their jobs during the pandemic and of those who had kept their jobs, 68 per cent had had their wages reduced (Hajjar and Abu-Sittah 2021: 1). A study carried out by the International Labour Organization (ILO) in Lebanon also found that 60 per cent of Syrian refugees had been permanently laid off and 31 per cent temporarily laid off from jobs during the pandemic (Hajjar and Abu-Sittah 2021: 5). A survey carried out in 2020 in seven Latin American countries found a drop in income of 80 per cent amongst forcibly displaced Venezuelan families (Valette et al. 2021: 11). A survey carried out amongst refugee families in Uganda in 2020 found that 47 per cent suffered from large reductions in revenue and 11 per cent received no income at all (Valette et al. 2021: 11). A separate high-frequency phone survey in Uganda found that 13 per cent of refugees had stopped working in March 2020 (Atamanov et al. 2021a: 5). The total household income had declined or dried up for 89 per cent of refugee households in Uganda since March 2020 (Atamanov et al. 2021a: 5). Underemployment was also an issue there, with refugees working fewer hours than before lockdown (Atamanov et al. 2021b: 7).

Forcibly displaced persons have been found to be more likely to have lost income as a result of the pandemic than their host communities. For example, in Jordan, 35 per cent of Syrian refugees lost their employment as a result of the pandemic compared to 17 per cent of Jordanian citizens, while in Lebanon, 60 per cent of Syrians lost their jobs permanently compared to 39 per cent of Lebanese citizens (Vallette et al. 2021: 13). A study of eight host countries found that refugees were 60 per cent more likely than host populations to be working in sectors such as accommodation and food services, manufacturing and retail, which have been highly impacted by pandemic restrictions (Dempster et al. 2020: 1). The first round of a high-frequency phone survey in Uganda found that the employment rate of refugees was significantly lower than that of the host community during autumn 2020 (43 per cent compared to 90 per cent), especially for refugees in Kampala (27 per cent) (Atamanov et al. 2021a: 5). The second round of the survey, carried out a month later, found a decline in the employment rate of refugees, which had fallen to 36 per cent by then (Atamanov et al. 2021b: 7).

Research by CARE focusing on forcibly displaced women in Afghanistan, Ecuador and Turkey found that 67 per cent of women in Afghanistan and 70 per cent in Turkey reported that their household income had decreased during the Covid-19 
pandemic, while 67 per cent of migrant/refugee women in Ecuador said their income sources had been 'completely' affected (Osborn 2021: 3). This was driving their households 'deeper into poverty and to a breaking point, reducing health care expenditures and increasing food insecurity' (Osborn 2021: 3).

\section{Impact of lost income}

As a result of their drops in income, 30 per cent of NRC survey respondents had to borrow more money than before the pandemic to cover their costs for food, education or rent (Gorevan 2020: 3). In Afghanistan, this figure was as high as 41 per cent, although it was only 6.5 per cent in Kenya, the survey country where it was lowest (Gorevan 2020: 10). Increased borrowing was also significant in Iraq (28 per cent) and Uganda (24 per cent) (Gorevan 2020: 10). In addition, 71 per cent of respondents had difficulty paying rent or covering other basic housing costs, and 47 per cent reported they had been evicted since March 2020 (rising to 69 per cent in Afghanistan), with many others fearing or being threatened with eviction (Gorevan 2020: 3, 19-20; NRC 2020b: 2). In Iraq, the threat of eviction was found to be greater for women (90 per cent compared to 55 per cent of men) (Gorevan 2020: 20). Women were also at greater risk of eviction in Afghanistan (NRC 2020b: 3). Evidence from Uganda suggests that urban refugees are at greater risk of eviction than those living in rural areas (Gorevan 2020: 20). Over 70 per cent of NRC respondents were also unable to meet the expenses for their children's education and medical care (Gorevan 2020: 3). The economic impacts have mounted over time, with increases in the number of respondents in Iraq, for example, who said they would not be able to pay their rent or pay back the debts they had accumulated (Gorevan 2020: 10).

Loss of income had knock-on effects on other aspects of the lives of forcibly displaced persons, according to the World Vison research: 71 per cent reported being unable to meet rental needs, 69 per cent reported being unable to meet education needs, and 68 per cent reported being unable to meet health-care needs (Vallette et al. 2021: 11). None of the 129 Syrian refugee families interviewed in Lebanon were able to meet all their basic needs, with 45 per cent of them not being able to afford them at all (Hajjar and Abu-Sittah 2021: 1). Ninety-two per cent of families had taken on new financial debts during the pandemic (Hajjar and Abu-Sittah 2021: 4). Eighty-eight per cent of participants reported that the lockdown caused constant stress at home (Hajjar and Abu-Sittah 2021: 4). Other research by NRC in Afghanistan found that the 'loss of livelihoods and a dire food security and nutrition situation has left people to use up their savings and take on debt, cut meals and medical expenses, and risk being evicted from their homes' (NRC 2020b: 1).

In addition, loss of income has significant psychological impacts and increases stress and tensions in households. The World Vision survey found that 77 per cent of respondents reported increased levels of stress, as well as tensions in the home, with knock-on effects on the psychosocial wellbeing of children (Vallette et al. 2021: 13). In addition, a WHO survey of over 30,000 respondents found that one in five respondents had increased their drug and alcohol use as a result of the pandemic, especially those with insecure status (WHO 2020: viii, 16). 


\section{Food insecurity}

Even before the Covid-19 pandemic, refugees, internally displaced people and host communities faced worrying levels of food insecurity, and this has been a major issue during the pandemic, owing to a combination of factors, such as lost income and livelihoods, increased food and transport costs, and food shortages (Gorevan 2020: 15, 17; Amnesty International 2021: 7). In addition, globally women are more likely than men to suffer from food insecurity, with women, adolescent girls, and young children at heightened risk of malnutrition, as in societies where females are considered to be of lower status than men, women and girls receive less food than their male counterparts, especially in crises, when food is limited (UNFPA 2016; Hazard 2020: 17).

In Yemen, 94 per cent of people surveyed by NRC reported that prices for food, water and other basic items had gone up since the arrival of Covid-19, contributing to the number of households without enough to eat jumping from 29 per cent in May 2020 to 36 per cent in June 2020 (Gorevan 2020: 17). For people living in isolated areas or areas of high conflict, the June figure is higher, at 42 per cent (Gorevan 2020: 17). In Uganda, 85 per cent of households had run out of food because of lack of money or other resources in October/November 2020 (Atamanov et al. 2021a: 5). However, in December 2020 fewer households were experiencing 'the most severe forms of food insecurity such as going without eating for a whole day and not eating even when hungry' (Atamanov et al. 2021b: 7). Seventy-seven per cent of respondents in World Vision's survey reported that they could not meet their food needs (Vallette et al. 2021: vi). In some countries, such as the Democratic Republic of Congo, this figure was even higher, with more than 90 per cent of respondents reporting being unable to fully meet their food needs (Vallette et al. 2021: 11). Respondents were coping with reduced incomes and food insecurity by cutting down on food or buying less nutritious food (Vallette et al. 2021: 15).

Refugees and internally displaced persons mentioned that poor diet or lack of access to food was their top concern in relation to children during the pandemic (Vallette et al. 2021: vii, 15). This concern about children's nutrition is also reflected in other research, with the UN reporting that in March 2021, "half a million children in Syria were chronically malnourished, and that in some areas of northwest Syria, acute malnutrition was approaching the emergency threshold of 15\% amongst displaced children living in camps and hard to reach areas' (Vallette et al. 2021: 15). Research with adolescents from Rohingya refugee and host communities in Cox's Bazar, Bangladesh, found that food insecurity was one of the most severe and concerning impacts of Covid-19 in both communities, with reduced food rations and less food being purchased (Guglielmi et al. 2020: 4). Survey data showed that '58\% of Rohingya households reported cutting back on food served to boys and/or girls' (Guglielmi et al. 2020: 5). In the camps, girls were more likely to report experiencing hunger as a result of the pandemic (22 per cent compared to 14 per cent of boys) (Guglielmi et al. 2020: 5).

CARE's research in Afghanistan found that 100 per cent of women who were internally displaced or returned refugees reported that households in their 
community were relying on less expensive or less preferred food (Osborn 2021: 3). 'Food shortages are felt even more acutely by women, who are most often held responsible for providing and preparing the family's food, putting women under additional stress' (Osborn 2021: 3). Access to food also differed for refugees in Uganda, with female-headed households less likely to be able to buy their main staple food than male-headed households (Atamanov et al. 2021b: 8).

NRC's multi-country survey found that 73 per cent of respondents had had to cut the number of meals for their household since the pandemic broke out (Gorevan 2020: 15). In Afghanistan, this was as high as 81 per cent, in Iraq it was 66 per cent, in Kenya 65 per cent, and in Uganda it was 55 per cent (Gorevan 2020: 16). Research carried out by the International Organization for Migration (IOM) in Yemen found that 69 per cent of respondents had reduced the number of meals they consumed per day (Jourdain et al. 2021: 33). Forty-five per cent of internally displaced persons in Libya had reduced meal sizes or bought less expensive food (Jourdain et al. 2021: 33). Research in Cox's Bazar in April 2020 also found that 72 per cent of refugees and 59 per cent of the host community had been unable to buy essential food items in the seven days prior to being surveyed and that they were resorting to buying lowerquality or cheaper food, skipping meals or reducing food portions (Vishvanath et al. 2020: 16). Research with internally displaced persons in Afghanistan by Amnesty International also found that 'they either had not received any food-related relief or it has been completely insufficient to help them survive the crisis' (Amnesty International 2021: 18). This meant that they were forced to borrow money to feed their families, resulting in debt which is increasingly difficult to pay back in the absence of any work opportunities or other means of income support (Amnesty International 2021: 18).

\section{Negative coping mechanisms}

'Considering their low level of assets, limited access to credit and insurance markets, and constraints in accessing safety nets, refugees' available coping strategies in response to income losses are limited' (Vishvanath et al. 2020: 16). As noted above, forcibly displaced persons have responded to their loss of income with a variety of coping mechanisms, some of which have long-term implications for their ability to recover. A study of mobile populations across the Middle East and North Africa (MENA) region found that coping strategies, including negative coping strategies, to deal with the economic fall-out of the pandemic included borrowing money from friends and relatives, reducing food-related expenses and food consumption, reducing spending on other essential expenses, increased use of savings and/or selling of assets, and being compelled to accept work (including sex work) under exploitative conditions (Jourdain et al. 2021: 33). For example, CARE's research in Afghanistan found that 67 per cent of women who were internally displaced or returned refugees reported reducing their expenditure on medication, hygiene items and clothing (Osborn 2021: 3). NRC's research in Afghanistan found that over 80 per cent of the most vulnerable displaced families had taken on debt but still could not afford to meet their basic needs and pay their rent, leading to increased levels of borrowing (NRC 2020b: 2). In Uganda, the most frequent reason to borrow money 
was to buy food (Atamanov et al. 2021b: 9). However, not all these coping mechanisms are available to all forcibly displaced persons as few have enough savings to get them through the pandemic, for example, or family and friends' ability to lend is impacted by their own terrible economic situation during the crisis (Jourdain et al. 2021: 33; Gorevan 2020: 10).

Jacobsen et al. (2020: 77) warn that displaced women and people with diverse sexual orientation and gender identity or expression, will struggle to find new ways of securing income during the pandemic, which has the potential to increase the incidence of coping strategies such as transactional sex, which was found to increase during the Ebola outbreak in West Africa. Food insecurity has been found to be a common reason to engage in transactional sex (Jacobsen et al. 2020: 78).

Transactional sex also leads to a higher risk of unwanted pregnancy, pregnancy complications and unsafe abortions, as well as an increased risk of HIV and other sexually transmitted infections, sexual and gender-based violence and mental health problems (Jacobsen et al. 2020: 78).

There were some specific risks for children. The socioeconomic fall-out of the pandemic means forcibly displaced children have faced increased risks of 'violence, abuse and exploitation, for instance in the form of child labour, trafficking for sexual exploitation, or child marriage [which affects] adolescent girls in particular', as a result of the economic pressure faced by their families (UN 2020: 14; Amnesty International 2021: 20; Duclos and Palmer 2020: 8; NRC 2020b: 3; Guglielmi et al. 2020: 5). In the Democratic Republic of Congo for example, 43 per cent of respondents in World Vision's survey reported that they had to send their children out to work to cope with income/job losses (Vallette et al. 2021: 16). CARE's research in Afghanistan found that 63 per cent of women who were internally displaced or returned refugees reported sending children under 18 out to work (Osborn 2021: 3). World Vision's survey also noted that 17 per cent of respondents reported child marriage as a concern in Uganda, as did 8 per cent in the Democratic Republic of Congo and 5 per cent in Jordan (Vallette et al. 2021: 17). There was mixed evidence about whether child marriage has been exacerbated by the pandemic in refugee camps in Bangladesh, with adolescents both worrying about child marriage and feeling that there was less pressure than before (Guglielmi et al. 2020: 5).

\section{Support for refugees}

Covid-19 has further constrained the ability of organisations to deliver assistance to forcibly displaced persons. This is due to a combination of reduced capacity caused by decreased funding, shifts in programming to Covid-19, travel bans, local lockdowns and staff illness during the pandemic (Jourdain et al. 2021: 28; Jacobsen et al. 2020: 77; Duclos and Palmer 2020: 11; Hazard 2020: 20). The provision of social protection and humanitarian aid for forcibly displaced persons during the pandemic was limited and inconsistent across, and within, countries. In Uganda, for example, the type of assistance differed by location, with refugees in the West Nile region more likely to get food and other in-kind assistance, while refugees in the South West region were more likely get cash transfers, with refugees in Kampala the least likely to get any 
social assistance, as they often have more uncertain legal status and are not covered by official assistance (Atamanov et al. 2021a: 6; Duclos and Palmer 2020: 4; Bukuluki et al. 2020: 1). Urban refugees elsewhere have also received less support than those in camps or settlements, as UNHCR tends to concentrate its efforts on the latter, and emergency initiatives to distribute cash to urban refugees have been much slower and have not achieved complete coverage (Duclos and Palmer 2020: 11).

Organisations supporting internally displaced persons in Yemen had to start reducing humanitarian aid because of lack of funds, despite the increased need caused by Covid-19 (Anaam 2021: 498). Twenty-eight per cent of respondents to NRC's survey had received less humanitarian assistance than before the Covid-19 outbreak (Gorevan 2020: 4).

Even before the pandemic, the access of forcibly displaced persons to national social safety nets was extremely limited (Vishvanath et al. 2020: 13). Social protection support for refugees during the pandemic has generally come from humanitarian or development actors rather than governments, except in some Latin American and Caribbean countries, which continued their pre-pandemic policy of support (HagenZanker and Both 2021: i; Duclos and Palmer 2020: 11). The high involvement of forcibly displaced persons in the informal sector means they 'have less job security and are less protected against job and income loss, and their refugee status often prevents them from accessing government provided health and social safety nets' (Dempster et al. 2020: 14). Efforts to support refugees underwent delays and challenges to timely implementation, especially in places lacking existing registries, such as Pakistan and the Republic of Congo, where most target beneficiaries only received payments more than six months after the first lockdown (Hagen-Zanker and Both 2021: 1). Coverage of refugee populations was also generally low, and the benefits provided were not enough to meet their needs (Hagen-Zanker and Both 2021: 1-2).

While there is limited evidence that the pandemic has led to any significant change in the approach taken towards refugees' social protection, Hagen-Zanker and Both (2021: 2) suggest that marginal changes, such as removing certain barriers to access, including refugees in socioeconomic surveys, and intensifying interactions between international humanitarian and development actors and governments, may lead to greater inclusion in the future.

In addition, responses have built on existing local social and aid-delivery structures, as well as involving refugee-led organisations, who have 'functioned as important actors in solidarity networks to address the gaps and limitations of existing international aid and host government support systems in providing food relief for self-settled groups' (Duclos and Palmer 2020: 15). Duclos and Palmer (2020: 18) suggest that such efforts at localisation can help address the current and future vulnerabilities of forcibly displaced persons. 


\section{Social impacts}

\section{Loss of education}

Children make up more than half of the world's refugees and 42 per cent of all internally displaced persons, and the already precarious access to education of displaced and refugee children has been disrupted by the months of widespread school closures and their familes' loss of income (UN 2020: 14-15; x; Vallette et al. 2021: 18; Gorevan 2020: 21; NRC 2020b: 3). Ninety per cent of refugee children had reduced access to education (UNCHR 2021b: 1). In Uganda, only 58 per cent of children who had been in school were engaging in educational or learning activities during the school closures in October/November 2020 (Atamanov et al. 2021a: 5). By December this had increased to 70 per cent, although many were doing activities with the lowest learning potential, such as studying alone and doing homework provided by parents (Atamanov et al. 2021b: 8). Amongst the 129 Syrian families in Lebanon, 70 per cent of children did not continue their education at home during the pandemic (Hajjar and Abu-Sittah 2020: 1). Only 19 per cent of all respondents' children in the World Vision multi-country survey were reported to have access to the internet for study purposes, whilst just 10 per cent were reported to have access to paper-based school materials, meaning that home schooling was not really occurring for these children (Vallette et al. 2021: 19).

NRC's multi-country survey found that three-quarters of respondents were less likely to send their children to school because of their economic situation (Gorevan 2020: 21). In Afghanistan, 83 per cent of respondents said they were less likely, in Iraq it was also 83 per cent, in Kenya it was 82 per cent and in Uganda it was 55 per cent (Gorevan 2020: 21). Research in Libya found that 74 per cent of the internally displaced persons surveyed said they would be less likely to send their children back to school, owing to their weakened economic situation (Jourdain et al. 2021: 33). Children who are forced to work to help with their family's economic problems may struggle to return to school even after the public health crisis subsides (UN 2020: 15).

Education disruptions have also affected school-feeding programmes and removed a protective environment for children (Vallette et al. 2021: 18; Osborn 2021: 4; Gorevan 2020: 22). Older forcibly displaced girls are particularly at risk of dropping out of school permanently (UNHCR 2021b: 1).

\section{Gender-based violence}

Lockdown measures and confinement, as well as increased socioeconomic pressures and school closures, heighten displaced women and girls' risks of gender-based violence, especially intimate partner violence (UN 2020: 14; Vallette et al. 2021: 17; Amnesty International 2021: 14, 20; Osborn 2021: 3; UNHCR 2021). Their overcrowded and precarious living and working conditions also expose them to greater risk of sexual harassment and exploitation (UN 2020: 14). The UNHCR noted that they were seeing 'extremely worrying increases in reports of gender-based violence, including domestic violence, forced marriages, child labour and adolescent pregnancies' 
(UNHCR 2021). Forcibly displaced women and girls, especially if they are undocumented, are reluctant to access gender-based violence services because they fear retaliation, stigma, detention and possible deportation if such services aren't firewalled, while such services have also been impacted and reduced by the pandemic (UN 2020: 14; Amnesty International 2021: 14; Osborn 2021: 4). UNHCR's protection chief notes that ' $[\mathrm{d}]$ isabilities, marginalisation, diverse sexual orientation and gender identities are also compounding discrimination and risks of violence for refugee, displaced and stateless women and girls' (UNHCR 2021).

CARE's research found that between 16 per cent and 39 per cent of women on the move reported that the risk of violence and abuse of women and girls in their communities, especially within their families, had increased during the pandemic (Osborn 2021: 3-4). In Afghanistan, almost 88 per cent attributed this to increased male unemployment (Osborn 2021: 3). Almost half of the women interviewed also reported feeling more excluded from gender-based violence services than they did before the pandemic (Osborn 2021: 4).

\section{Access to sexual and reproductive health services}

As with women across the world, forcibly displaced women and girls have also struggled to access sexual and reproductive health services during the pandemic (Osborn 2021: 3; Bukuluki et al. 2020: 2). Access to such services has been restricted globally because they have been side-lined, resources have been diverted, health workers have lacked personal protective equipment, and women have not been able to travel to clinics or have stayed away for fear of contracting Covid-19 (Rohwerder 2020: 4). Research by CARE in Afghanistan, Ecuador and Turkey between April and May 2021 with displaced populations found that 46 per cent of women on the move in these countries had had less or no access to safe maternity care since the start of the pandemic, especially in Afghanistan, where the figure was 51 per cent (Osborn 2021: 3). In addition, 46 per cent of displaced women in Afghanistan had less or no access to family planning counselling and sexual and reproductive health services during the pandemic (Osborn 2021: 3).

\section{Stigma and xenophobia}

Forcibly displaced people across the world have reported 'experiencing increased xenophobia, hate speech and both physical and emotional attacks since the start of the pandemic' (Vallette et al. 2021: vi). In some places, responses to the pandemic, such as quarantines targeted at refugee camps rather than including them in the same responses as the host community, or political rhetoric blaming forcibly displaced persons as a threat and carriers of the virus, have contributed to xenophobia and hate crimes targeting displaced people (Rohwerder 2021: 35; Duclos and Palmer 2020: 9). UNHCR (2021a) found 43 countries with reported or known instances of xenophobia, stigmatisation or discrimination. Respondents from all the World Vision survey countries reported such experiences, especially those in Peru (46 per cent of respondents), followed by 28 per cent of respondents from Colombia, 15 per cent from Brazil and 10 per cent from Turkey (Vallette et al. 2021: 9). Research with 
urban refugees in Uganda found that as Covid-19 is considered to be 'imported', they were assumed to be potential transmitters, leading to heightened stigma and isolation (Bukuluki et al. 2020: 2). The WHO survey found that a significant proportion of respondents felt that discrimination had worsened during the pandemic, especially instances that involved being avoided, being feared, being treated differently, being called names, and being unfairly treated by the police (WHO 2020: 18). Those in more secure situations, such as houses or refugee camps, were less likely to feel that they experienced increased discrimination than were people living on the street, in insecure accommodation or in asylum centres (WHO 2020: 18).

\section{Reduced social cohesion}

In some contexts, the pandemic has had an impact on the social cohesion between displaced people and host communities (Jourdain et al. 2021: 13). Fear of Covid-19 and its increasing human and financial toll 'has resulted in increasing tensions between displaced populations and host communities, sometimes tapping into existing tensions' (Rohwerder 2021: 35).

Food support provided to internally displaced persons in Afghanistan created a backlash amongst host communities in the context of scarce resources as they felt it should also be going to other vulnerable community members (Amnesty International 2021: 22). A study by IOM in the MENA region found that increased competition for resources had led to increased conflict and tension between host communities and mobile communities, but that in some cases it also had led to increased empathy and to acts of solidarity with displaced communities (e.g. distributions of food or hospitality from community-based organisations and hosts) (Jourdain et al. 2021: 13). In addition, in Uganda, the pandemic has lowered the interaction between refugees and Ugandans, with 42 per cent of refugee households reporting less frequent interactions with host community members since it began (Atamanov et al. 2021b: 9).

\section{Reduced access to registration and civil documentation}

Refugee registration and civil documentation is essential for ensuring that forcibly displaced persons can stay legally in their host countries and access to essential services such as health care (Osborn 2021: 28). The Covid-19 pandemic has resulted in new or additional challenges to accessing such documentation, as a result of services shutting down or reducing their capacity in order to make processes Covid-safe (Osborn 2021: 28; Rohwerder 2021: 24). In addition, research looking at the right to asylum of refugees during the pandemic noted that 'some countries have used the pandemic as a reason to not accept new asylum requests and/or suspend pending applications as they claimed they are unable to conduct interviews and process 
cases, leaving asylum seekers stuck in limbo, often in atrocious conditions'l (Rohwerder 2021: 6).

CARE's research noted that the pandemic was resulting in increased challenges for displaced women in accessing registration and legal and civil documentation (26 per cent on average reported new or additional challenges across the three countries and 22 per cent reported this in Afghanistan) (Osborn 2021: 4, 28). In Afghanistan, those facing challenges accessing documentation mainly mentioned this occurring in the case of identity documents, birth certificates and marriage certificates (Osborn 2021: 29). Uganda suspended its refugee status determination processes, affecting the ability of asylum seekers to access assistance (NRC 2020a; Bukuluki et al. 2020: 2).

\section{References}

Amnesty International (2021) 'We survived the virus, but may not survive the hunger': The Impact of Covid-79 on Afghanistan's Internally Displaced, London: Amnesty International

Anaam, F.M.S. (2021) 'Challenges and Difficulties of Internally Displaced People of Yemen amid Covid-19', International Research Journal of Modernization in Engineering Technology and Science, 3.1: 496-500

Atamanov, A.; Yoshida, N.; Beltramo, T.P.; Rios Rivera, L.A.; Sarr, I.; Waita, P. and Yoshimura, K. (2021a) Monitoring Social and Economic Impacts of COVID-79 on Refugees in Uganda: Results from the High-Frequency Phone Survey - First Round, Munich Personal RePEc Archive Paper No. 106425

Atamanov, A.; Yoshida, N.; Alemi, C.; Beltramo, T.; llukor, J.; Rios Rivera, L.A.; Sarr, I.; Said, A.H.; Waita, P. and Yoshimura, K. (2021b) Monitoring Social and Economic Impacts of COVID-79 on Refugees in Uganda: Results from the High-Frequency Phone SurveySecond Round, Washington, DC: World Bank

Bukuluki, P.; Mwenyango, H.; Katongole, S.P.; Sidhva, D. and Palattiyil, G. (2020) 'The Socio-economic and Psychosocial Impact of Covid-19 Pandemic on Urban Refugees in Uganda', Social Sciences \& Humanities Open 2.1, doi: 10.1016/j.ssaho.2020.100045

Dempster, H.; Ginn, T.; Graham, J.; Guerrero Ble, M.; Jayasinghe, D. and Shorey, B. (2020) Locked Down and Left Behind: The Impact of COVID-79 on Refugees' Economic Inclusion, Washington, DC: Center for Global Development and Refugees International

\footnotetext{
${ }^{1}$ However, as the pandemic progressed 'at least 82 countries have adapted registration of new asylum applications by mail, phone, email or other online mechanisms, while at least 86 have adapted measures to issue new, or extend the validity, of asylum documentation' (Rohwerder 2021: 25).
} 
Douedari, Y.; Alhaffar, M.; Al-Twaish, M.; Mkhallalati, H.; Alwany, R.; Ibrahim, N.B.M.; Zaseela, A.; Horanieh, N.; Abbara, A. and Howard, N. (2020) '“Ten years of war! You expect people to fear a "germ'?": A Qualitative Study of Initial Perceptions and Responses to the COVID-19 Pandemic Among Displaced Communities in OppositionControlled Northwest Syria', Journal of Migration and Health 1-2: 1-8, doi: 10.1016/j.jmh.2020.100021

Duclos, D. and Palmer, J. (2020) Background Paper: Covid-79 and Forced Displacement in the Middle East and East Africa, Brighton: Social Science in Humanitarian Action (SSHAP)

Gorevan, D. (2020) Downward Spiral: The Economic Impact of Covid-79 on Refugees and Displaced People, Oslo: Norwegian Refugee Council

Guglielmi, S.; Seager, J.; Mitu, K.; Baird, S. and Jones, N. (2020) 'Exploring the Impacts of COVID-19 on Rohingya Adolescents in Cox's Bazar: A Mixed-Methods Study', Journal of Migration and Health 1-2, doi: 10.1016/j.jmh.2020.100031

Hagen-Zanker, J. and Both, N. (2021) Social Protection Provisions to Refugees During the Covid-79 Pandemic - Lessons Learned from Government and Humanitarian Responses, ODI Working Paper 612, London: Overseas Development Institute

Hajjar, M.S. and Abu-Sittah, G.S. (2021) 'The Multidimensional Burden of COVID-19 on Syrian Refugees in Lebanon', Journal of Global Health 11, doi: 10.7189/jogh.11.05004

Hazard, E. (2020) Covid-79 Impacts on African Children: How to Protect a Generation at Risk. Nairobi and Dakar: Save the Children East and Southern Africa Regional Office and Save the Children West and Central Africa Regional Office

Jacobson, L.; Regan, A.; Heidari, S. and Onyango, M.A. (2020) 'Transactional Sex in the Wake of COVID-19: Sexual and Reproductive Health and Rights of the Forcibly Displaced', Sexual and Reproductive Health Matters 28.1, doi: 10.1080/26410397.2020.1822493

Jourdain, J.; Bertini, R.; Arnold, D. and Rossi, L. (2021) Assessing the Socio-economic Impact of COVID-79 on Migrants and Displaced Populations in the Middle East and North Africa, Cairo: IOM Middle East and North Africa Regional Office

United Nations High Commissioner for Refugees (UNHCR) (2021) COVID-19 Pandemic Worsening Gender Inequalities for Refugee Women and Girls. Press Release, UNHCR UK

Norwegian Refugee Council (NRC) (2020a) The Humanitarian Impact of Covid-79 on Displaced Communities, Oslo: NRC

Norwegian Refugee Council (NRC) (2020b) On the Brink: Displacement-Affected Communities in Afghanistan During the Covid-79 Pandemic, Oslo: NRC 
Osborn, C. (2021) Magnifying Inequalities and Compounding Risks: The Impact of COVID-79 on the Health and Protection of Women and Girls on the Move, Atlanta, GA: CARE

Rohwerder, B. (2020) Social Impacts and Responses Related to COVID-79 in Low- and Middle-Income Countries, K4D Emerging Issues Report 35, Brighton: Institute of Development Studies

Rohwerder, B. (2021) The Right to Protection of Forcibly Displaced Persons During the Covid-19 Pandemic, IDS Working Paper, Brighton: Institute of Development Studies

United Nations (UN) (2020) Policy Brief: COVID-79 and People on the Move, New York: UN

United Nations Population Fund (UNFPA) (2016) 10 Things You Should Know About Women \& the World's Humanitarian Crises, New York: UNFPA

United Nations High Commissioner for Refugees (UNHCR) (2021a) Covid-79 Platform Temporary Measures and Impact on Protection, Geneva: UNHCR (accessed 19 July 2021)

United Nations High Commissioner for Refugees (UNHCR) (2021b) UNHCR's Global COVID-79 Needs - February 2027, Geneva: UNHCR

Vallette, D.; Nepesova, N. and Korobkova, N. (2021) High Risk - Low Priority: Why Unlocking COVID-79 Vaccine Access for Refugees and Internally Displaced Communities is Critical for Children, Uxbridge: World Vision International

Vishvanath, T.; Alik-Legrange, A. and Aghabarari, L. (2020) Highly Vulnerable Yet Largely Invisible - Forcibly Displaced in the COVID-79-Induced Recession. JDC Paper Series on Forced Displacement 1, Copenhagen: Joint Data Center on Forced Displacement

World Health Organization (WHO) (2020) Apart Together Survey: Preliminary Overview of Refugees and Migrants Self-reported Impact of COVID-79, Geneva: WHO

\section{Suggested citation}

Rohwerder, B. (2021) The Socioeconomic Impacts of the Covid-19 Pandemic on Forcibly Displaced Persons, Covid Collective Helpdesk Report 6, Brighton: Institute of Development Studies, DOI: 10.19088/CC.2021.006 


\section{About this report}

This report is based on 6 days of desk-based research. The Covid Collective research helpdesk provides rapid syntheses of a selection of recent relevant literature and international expert thinking in response to specific questions relating to international development. For any enquiries, contact Covid Collective- covidcollective@ids.ac.uk.

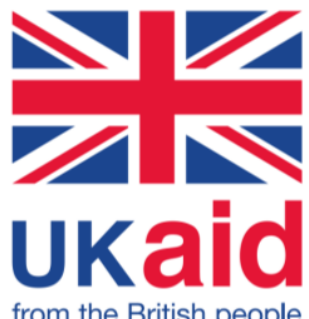

This evidence summary was funded by the UK Government's Foreign, Commonwealth and Development Office (FCDO) through the Covid Collective. It is licensed for non-commercial purposes only. Except where otherwise stated, it is licensed for non-commercial purposes under the terms of the Open Government Licence v3.O. Covid Collective cannot be held responsible for errors, omissions or any consequences arising from the use of information contained. Any views and opinions expressed do not necessarily reflect those of FCDO, Covid Collective or any other contributing organisation.

(c) Crown copyright 2021. 